\title{
EFFICIENT TIME BARS: A NEW RATIONALE FOR THE EXISTENCE OF STATUTES OF LIMITATIONS IN CRIMINAL LAW
}

\author{
YAIR LISTOKIN* \\ Princeton University
}

\begin{abstract}
This paper proposes a novel normative economic explanation for statutes of limitations for criminal offenses. Because potential criminals tend to discount the future at higher rates than society, punishing crimes long after they are committed will be inefficient. Punishments after a long lag have only a nominal deterrent effect, while they may cost society substantial sums. The model presented in the paper derives the optimal statute of limitations for a crime by modifying the standard model of public enforcement of law to consider lags between crime and punishment. In addition, numerical simulations of the model suggest that some U.S. statutes of limitations are generally consistent with optimal limitations (probably serendipitously). Finally, the paper employs the model to critique several tenets of the law concerning statutes of limitations.
\end{abstract}

\section{INTRODUCTION}

$\mathbf{S}_{\mathrm{r}}$ ATUTES of limitations for criminal offenses have been a feature of U.S. criminal law since the early days of the Republic. ${ }^{1}$ Interestingly, however, the rationale for statutes of limitations in criminal law is subject to controversy. (A statute of limitations is defined as a "legislative act restricting the time within which legal proceedings may be brought.") ${ }^{2}$ Most legal scholars posit that criminal statutes of limitations are chosen to balance society's need to punish a criminal with some countervailing factor. For some, the primary countervailing factor is a "criminal's right to repose." ${ }^{3}$ Others emphasize that

* I would like to thank Debopam Bhattacharya, Chang-Tai Hsieh, Gad Levanon, Aprajit Mahajan, Steven Shavell, Dave Skeie, Alessandro Tarozzi, Jim Vere, Stephanie Wexler, an anonymous referee, and the participants in Princeton University's Development Lunch Seminar for their helpful comments and suggestions. I am especially grateful to Anne Case for her invaluable help and guidance. All errors are my own.

' Note, Developments in the Law: Statutes of Limitations, 63 Harv. L. Rev. 1177, 1177 (1950).

${ }^{2}$ Encyclopedia Britannica, s.v. "statutes of limitations" (2000).

${ }^{3} \mathrm{~J}$. Anthony Chavez, Statutes of Limitations and the Right to a Fair Trial: When Is a Crime Complete? 10 Crim. Just. 2, 2 (1995) (the right of repose suggests that an individual should not have to live with the uncertainty of prosecution, and thus at the mercy of prosecutors, ad infinitum); See also United States v. Toussie, 397 U.S. 112, 115 (1970).

[Journal of Legal Studies, vol. XXXI (January 2002)]

(C) 2002 by The University of Chicago. All rights reserved. 0047-2530/2002/3101-0005\$01.50 
the quality of evidence deteriorates with time and assert that fairness requires timely prosecution. ${ }^{4}$ Most legal scholars subscribe to some combination of these two standards.

While these explanations have the advantage of echoing the standard rationales for statutes of limitations in civil law, they have been the subject of some recent controversy. ${ }^{5}$ Many legal reformers of the 1970s and 1980s viewed statutes of limitations as a "formalistic impediment to full justice." These opinions were reflected in a series of statutes and decisions that weakened the scope and applicability of time bars (as statutes of limitations are frequently called). Some lawyers have decried this process. ${ }^{7}$ They note that the primary justifications for criminal statutes of limitations are still germane and, consequently, condemn the recent trend.

Criminal statutes of limitations are also far from universal. England, for example, has no general statute of limitations applicable to criminal actions. ${ }^{8}$ In addition, there is considerable variation in statutes of limitations for identical crimes across jurisdictions within the United States. For instance, statutes of limitations for low-level felonies range from 2 years in Kansas to no limit in several states, such as South Carolina, Wyoming, and Kentucky. ${ }^{9}$ These variations suggest that no existing rationale for criminal statutes of limitations is universally acceptable.

This paper posits a novel normative economic explanation for time bars on prosecution. According to the standard theory of public enforcement of law, expenditures on criminal justice are justified only if their marginal cost is lower than the marginal benefit of the expenditures in terms of fewer crimes. If criminals discount the future at a higher rate than society (a commonly accepted view within criminology) and punishing crimes is costly for society, then, at times well after the commission of a crime, punishing a crime is inefficient from a deterrence perspective. Suppose, for example, that potential criminals care nothing for events and expenditures that take place more than 5 years from the present, while society values expenditures 5 years hence at some finite amount. This implies that punishment for a crime more than 5 years after its commission is inefficient

\footnotetext{
${ }^{4}$ See United States v. Marion, 404 U.S. 307, 322 (1971); and Chavez, supra note 3.

${ }^{5}$ See Richard A. Posner, Economic Analysis of Law 587 (4th ed. 1992).

${ }^{6}$ Walter Olson, Stale Claims: How Long Should the Law Nurse Old Grievances? Reason Mag., November 2000, at 40.

${ }^{7}$ Chavez, supra note 3, at 2-3; and Olson, supra note 6. Both Chavez and Olson cite several statutes extending various statutes of limitations (such as 18 U.S.C. $\S 3283$ and 18 U.S.C. $\S 3286$ ) as well as cases in which the legal applicability of statutes of limitations was limited, such as United States v. Brechtel, 997 F. 2d 1108 (5th Cir. 1993); and United States v. Taliaferro, 979 F. 2d 1399 (10th Cir. 1992).

${ }^{8}$ See Encyclopedia Britannica, supra note 2; and Note, supra note 1, at 1177-78.

${ }^{9}$ See Kansas Statutes $\S 21-3106$; and Gary Ernsdorff \& Elizabeth Loftus, Let Sleeping Memories Lie? Words of Caution about Tolling the Statute of Limitations in Cases of Memory Repression, 84 J. Crim. L. \& Criminology 129-30 (1993).
} 
from a deterrence perspective. The punishment has positive costs but achieves no deterrence. Therefore, society may wish to constrain law enforcement officials from punishing crimes inefficiently by imposing a statute of limitations. ${ }^{10}$

As a result, statutes of limitations can be justified for reasons distinct from notions of a criminal's rights. Moreover, numerical simulations (presented below) suggest that the length of these optimal statutes of limitations is consistent with the range of statutes of limitations currently imposed by U.S. state statutes. This normative explanation is then employed to examine the desirability of statutes of limitations for monetary fines and to critique some of the recent case law and statutory developments concerning time bars for prosecution.

The "discounting" approach developed here is related to some previous studies of optimal law enforcement. For example, A. Mitchell Polinsky and Steven Shavell find that differential discounting by criminals versus society may imply that the optimal criminal sentence is not maximal. ${ }^{1 "}$ This result conflicts with the finding of maximal sentencing that is standard throughout much of the literature. ${ }^{12}$ This paper applies logic similar to Polinsky and Shavell's to examine statutes of limitations, a topic hitherto unexplored in the optimal law enforcement literature.

The paper proceeds as follows. Section II discusses the model of optimal statutes of limitations and presents some important comparative statics results. Section III presents a numerical simulation of the model and compares the results with existing criminal statutes of limitations. Section IV presents extensions of the model to other types of statutes of limitations. Section V discusses the applicability of this theory of statutes of limitations to current legal doctrine and concludes.

\section{A Model of Optimal Statutes of Limitations}

\section{A. Setup}

The model discussed in this section (and presented in the Appendix) follows the standard model of optimal public enforcement of law. ${ }^{13}$ As in the

\footnotetext{
${ }^{10}$ E-mail correspondence with Steven Shavell, Harvard Law School (November 2000). It must be mentioned, however, that there are many rationales for punishment aside from deterrence. Since retribution and incapacitation are also goals of punishment (amongst others), statutes of limitations longer than the "optimal" value found here may be warranted.

"A. Mitchell Polinsky \& Steven Shavell, On the Disutility and Discounting of Imprisonment and the Theory of Deterrence, 28 J. Legal Stud. 1 (1999).

${ }^{12}$ See A. Mitchell Polinsky \& Steven Shavell, The Economic Theory of Public Enforcement of Law, 38 J. Econ. Literature 50 (2000).

${ }^{13}$ See Polinsky \& Shavell, supra note 12 , for an extensive survey of this literature. See also A. Mitchell Polinsky \& Steven Shavell, The Optimal Use of Fines and Imprisonment, 24 J. Pub. Econ. 89 (1984); A. Mitchell Polinsky \& Steven Shavell, The Optimal Tradeoff between
} 
standard model, a potential criminal will weigh the gains associated with committing a crime against the crime's expected losses (potential imprisonment). The model differs from the standard model in that it allows punishment to occur with a lag after the crime is committed, as opposed to instantaneously. ${ }^{14}$ Because punishments occur after a lag and criminals discount the future, the same "nominal" prison term causes different "real" losses depending on when it is imposed.

An example best illustrates this principle. Suppose (for simplicity) that there is a 100 percent overall probability that a criminal will get caught for committing a crime and that when the criminal is caught the instantaneous disutility of the punishment is $\$ 10,000$. In the conventional model, the criminal will commit this crime if the gain from the crime is greater than $\$ 10,000$. If instead the criminal may (with equal probabilities of .5 in either period and therefore still a 100 percent overall probability of apprehension) be caught and punished either today or in 1 year's time and the criminal's discount rate is 25 percent, however, then the criminal will commit the crime if the gain is greater than $[.5 \times 10,000+.5 \times 10,000 /(1+.25)]=\$ 9,000 . \mathrm{Be}$ cause the punishment imposed after 1 year is discounted, the expected disutility associated with the crime is smaller.

The costs to society of imprisonment are also discounted if there are lags between crime and punishment. Suppose the criminal of the previous paragraph commits the crime and receives a 1-year sentence. If prison costs $\$ 20,000$ a year (and if the criminal in the previous paragraph commits a crime and is caught today), then the present discounted value of a 1-year prison sentence imposed today is $\$ 20,000$ (ignoring discounting within the year), while the present discounted value of the 1-year sentence imposed with equal probability either today or in 1 year if society has a 10 percent discount rate is $[.5 \times 20,000+.5 \times 20,000 /(1+.1)]=\$ 19,090$.

Adding a time dimension to the standard model introduces a new choice variable, the statute of limitations, to the standard instruments (such as sentence lengths and enforcement levels) considered by the public enforcement of law literature. A statute of limitations is an upper bound on the permissible length of the lag between crime and arrest or indictment. Returning to the example described above (where the probability of capture is .5 today and .5 in 1 year's time), suppose that the statute of limitations on prosecution is

the Probability and Magnitude of Fines, 69 Am. Econ. Rev. 880 (1979); Dilip Mookherjee \& I. P. L. Png, Monitoring vis-à-vis Investigation in Enforcement of Law, $82 \mathrm{Am}$. Econ. Rev. 556 (1992).

${ }^{14}$ This paper focuses on the lag between crime and arrest that occurs because it takes time for enforcement officers to detect and apprehend a criminal. See John Dilulio, Help Wanted: Economists, Crime and Public Policy, $10 \mathrm{~J}$. Econ. Persp. 3 (1996). This is different from active flight by criminals, which is better treated as a separate crime. See Ian Wiener, Running Rampant: The Imposition of Sanctions and the Use of Force against Fleeing Criminal Suspects, 80 Geo. L. J. 2175, 2183-84 (1992). 
6 months. In this case, the expected disutility from punishment becomes $.5 \times 10,000+.5 \times 0=\$ 5,000$, as criminals that are "caught" after 1 year cannot be punished owing to the statute of limitations. Similarly, the punishment costs associated with a crime to society become $.5 \times 20,000+$ $.5 \times 0=\$ 10,000$ as society uses imprisonment less because criminals caught after the statute of limitations are not punished.

A social planner should choose the statute of limitations exactly as she chooses the other instruments of public enforcement of law-with the goal of maximizing social welfare. In the model presented in the Appendix, society can choose the statute of limitations but takes the probability of apprehension and the length of the prison sentence as given. The statute of limitations should be chosen to minimize present discounted social costs, which include the harm associated with crimes and the present discounted cost of imprisonment.

The model makes two basic assumptions. The first assumption is that the crime should not have a statute of limitations of zero. This implies that the crime is one worth punishing.

The model's key assumption is that $\delta>\delta_{\text {soc }}$. In words, this assumption states that potential criminals discount the future at a faster rate $(\delta)$ than society $\left(\delta_{\mathrm{soc}}\right)$. Casual observation supports this assertion. While the nation debates the future of the Social Security system through the 2030s, many individuals (and particularly those in areas with high crime rates) patronize pawn shops charging interest rates of up to 100 percent. ${ }^{15}$

The assumption that $\delta>\delta_{\text {soc }}$ also receives support from a number of wellknown conclusions by criminologists. As one leading expert on crime has put it, many criminals are "radically present-oriented"; that is, they discount the future more heavily than the average person. ${ }^{16}$ Similarly, in a well-known study, James Wilson and Allan Abrahamse reject a number of popular interpretations of the motivations of career criminals and instead conclude that criminals are "temperamentally disposed to overvalue the benefits of crime and to undervalue its costs" because they are "inordinately impulsive or present-oriented."17 Two economists have interpreted this result to mean that criminals "discount punishments for . . . futurity more highly than other people." 18 In total, the as-

\footnotetext{
${ }^{15}$ See John Caskey, Pawnbroking in America: The Economics of a Forgotten Credit Market, 23 J. Money, Credit \& Banking 85 (1991); and Roger Swagler, John Burton, \& Joan Lewis, The Alternative Financial Sector: An Overview, 7 Advancing the Consumer Interest 7 (1995).

${ }^{16}$ See Dilulio, supra note 14, at 16-17. There may be complex psychological and sociological explanations for why criminals seem to be so consistently "present-oriented." For a more indepth look at the issue, see Mark Fleisher, Beggars and Thieves (1995); and James Q. Wilson \& Richard Herrnstein, Crime and Human Nature (1985).

${ }^{17}$ See James Q. Wilson \& Allan Abrahamse, Does Crime Pay? 9 Just. Q. 359 (1992). See also Wilson \& Herrnstein, supra note 16 , which describes criminals as "myopic."

${ }^{18}$ Robert Cooter \& Thomas Ulen, Law and Economics 465 (3d ed. 2000).
} 
sumption that $\delta>\delta_{\text {soc }}$ seems to be a well-founded one. ${ }^{19}$

Below, the model described here is employed to derive several implications regarding statutes of limitations.

\section{B. Results and Implications of the Model}

The model's chief implication is proposition 1:

Proposition 1. All crimes that are punished should have a finite statute of limitations.

Proof. For formal proof, see the Appendix.

As mentioned above, the statute of limitations should be chosen by the same criterion used to choose any other tool of law enforcement- to minimize social costs. Raising the statute of limitations has both marginal benefits and marginal costs. The marginal benefit comes in the form of increased deterrence. If the statute of limitations is lengthened, the expected punishment goes up. ${ }^{20}$ As a result, the gain required to make committing a crime worthwhile also goes up. Any criminal who formerly barely preferred to commit the crime is now deterred, and fewer crimes are committed. Added deterrence benefits society in two ways. With a reduction in crime, there is less direct harm associated with crime. In addition, a reduction in crime implies lower imprisonment expenditures as fewer individuals are sent to prison.

Lengthening the statute of limitations also has marginal costs, however. With a longer statute of limitations, more of the crimes that do occur will be punished. Since punishment is costly (prison terms cost money, and there is a deadweight loss from individuals languishing in jail), a longer statute of limitations implies higher criminal justice expenditures. To attain the social optimum, society should choose the statute of limitations at the point where the marginal benefit of raising the statute of limitations is equal to the marginal cost of that rise.

Because of the assumption that $\delta>\delta_{\text {soc }}$, moreover, there invariably comes a point at which the costs (in the form of higher criminal justice expenditures) of raising the statute of limitations will outweigh the benefits of the increase (as more crimes are deterred). First, note that (by assumption) if the crime is worth punishing, then the statute of limitations should not be zero. This implies that there is some range (from zero outward) in which the marginal benefits of raising the statute of limitations are higher than the marginal costs.

As the statute of limitations lengthens, both the marginal benefit and the marginal cost of raising the statute of limitations by a given amount tend to

\footnotetext{
${ }^{19}$ If criminals discount the future hyperbolically rather than exponentially (but still at high rates), the implications of discounting for statutes of limitations remain the same.

${ }^{20}$ In the example of the previous section, raising the statute of limitations from 6 months to 1 year raises the expected punishment from $\$ 5,000$ to $\$ 9,000$.
} 
go down. ${ }^{21}$ The marginal costs tend to go down because the present discounted value of the costs of punishing additional crimes as a result of raising the statute of limitations is getting progressively smaller. (A dollar spent 5 years from now on imprisonment is worth less than a dollar spent on prison today.) The marginal benefits of raising the statute of limitations tend to go down because the deterrent effect of punishing crimes far in the future is very small as a result of discounting. (A year spent in prison starting 5 years from now causes much less expected disutility today than a year spent in prison starting tomorrow and thus achieves less deterrence.)

Because criminals discount the future at a higher rate than society, the marginal benefits will tend to go down faster than the marginal costs. Moreover, since discounting is an exponential phenomenon, its effects will quickly dominate all other considerations. At some point, raising the statute of limitations will have essentially no deterrent effect, since discounting will have "eaten away" all the value of the punishment. This will make the marginal benefit of a further rise in the statute of limitations approximately (arbitrarily close to) zero. At this point, of course, the costs of raising the statute of limitations will also be much smaller because of discounting. ${ }^{22}$ Since criminals discount the future more heavily than society, however, discounting will erode the deterrence effects of longer statutes of limitations more quickly than it will erode the imprisonment cost side of the ledger. As a result, there is a point where the marginal benefits (from deterrence) of raising the statute of limitations are no longer greater than the marginal costs. This point is the optimal statute of limitations.

The model also offers some salient comparative statics results.

Proposition 2A. Crimes that cause more harm should have longer statutes of limitations for prosecution.

Proof. For a formal proof, see the Appendix.

As the harm associated with a crime goes up, the statute of limitations should become longer, ceteris paribus. When the harm associated with a crime rises, the marginal benefit of a rise in the statute of limitations (in the form of increased deterrence) also rises. Deterring a more pernicious crime has a greater benefit for society than deterring a less pernicious crime. As a result, if the harm associated with a crime rises, so too should the statute of

\footnotetext{
${ }^{21}$ Because few assumptions have been made about $Z(g)$ and $z(g)$ (see the Appendix for formal definitions of these terms), the marginal costs and benefits may not go down monotonically with increases in $n$. In symmetric distributions $(z(g))$ where the critical gain is above the mean, however, the marginal benefits and marginal costs of raising the statute of limitations do go down monotonically. With any $Z(g)$, the marginal costs and marginal benefits of raising the statute of limitations ultimately get arbitrarily close to zero.

${ }^{22}$ Note that even with very long (or infinite) statutes of limitations, complete deterrence (no crimes) is impossible, since there will always be some potential criminals with gains that are so high as to ensure that they will commit the crime. (In the formal terms of the Appendix, the distribution of $g$ has no upper limit.) Thus, there will always be some cost to lengthening the statute of limitations.
} 
limitations. This general principle is followed by almost all U.S. states. "Lowlevel" felonies, such as burglaries, tend to have much shorter statutes of limitations than crimes such as murder or rape. ${ }^{23}$

Additional comparative statics results require additional assumptions. For formal statements of these conditions, as well as proofs, see the Appendix. These assumptions roughly correspond to requirements that small changes in the discount rate should not cause a very large change in the number of potential criminals with gains from crime in the neighborhood of the critical gain. The conditions are met in any reasonable parameterization of these results. When these conditions are met, propositions $2 \mathrm{~B}$ and $2 \mathrm{C}$ apply.

Proposition 2B. When criminals discount the future more heavily, the statute of limitations should be shorter.

As criminals discount the future at a faster rate, the additional deterrence that results from longer statutes of limitations falls, since criminals care less about the prospect of the punishment far in the future. Ceteris paribus, this implies that the statute of limitations should be lowered, since the benefit of punishing crimes in the future has decreased (a long statute of limitations will deter few if any crimes) while the cost (additional imprisonment costs) has stayed the same.

With similarly messy but generally applicable assumptions, the model also implies the following:

Proposition 2C. As the disutility suffered by criminals from prison rises, the statute of limitations should become longer.

When the disutility criminals suffer from prison is greater, more criminals will be deterred by a given increase in the probability of jail. As a result, the marginal benefit of lengthening the statute of limitations rises (there is more deterrence and thus more crimes are prevented by a given increase in the statute of limitations), while the marginal cost remains the same, ceteris paribus. Thus, the statute of limitations should become longer.

\section{Numerical Simulation}

\section{A. Setup}

To provide a more concrete understanding of these results and to obtain some insight as to their relevance, this section presents a numerical simulation of the model detailed above. This section will simulate the social welfare function of the model presented in the Appendix (equation (A1) of the Appendix), taking as exogenous the values of all parameters except the statute of limitations. ${ }^{24}$ This exercise will be performed for three "levels" of felonies.

\footnotetext{
${ }^{23}$ See infra notes 35 and 39.

${ }^{24} \mathrm{~A}$ full understanding of the mechanics of this simulation would require a reading of the Appendix. Nevertheless, the "gist" of the simulations should be accessible without such a reading.
} 
A "low-level" felony (such as a larceny) has an estimated harm $(h)$ to society of $\$ 2,000 .{ }^{25} \mathrm{~A}$ "mid-level" felony, such as a robbery or burglary of a home, has an estimated harm of $\$ 10,000 .{ }^{26}$ Finally, a "high-level" crime (such as a murder or rape) is proxied as having a harm of $\$ 1$ million.

Where possible, the simulation employs empirically verified estimates for parameter values. For the exogenously determined sentence level $(t)$, for example, the simulation uses the sentencing guidelines (for each type of crime) published by the Federal Sentencing Commission for the year 1999. Prison and prosecution costs $(\alpha)$ are estimated at approximately $\$ 30,000-\$ 40,000$ per year. ${ }^{27}$ The disutility $(\lambda)$ that a criminal experiences from a year in prison is proxied by foregone earnings and is estimated at approximately $\$ 12,000-\$ 15,000$ per year. ${ }^{28}$ In addition, the simulation employs the rate at which states can borrow (approximately a 3-4 percent real rate, converted into exponential terms) as an estimate of the social discount rate $\left(\delta_{\text {soc }}\right)$. For the potential criminal's discount rate $(\delta)$, the simulation uses the interest rate charged at check cashing and pawn shops (approximately 35 percent, although the numbers are often far higher), converted into exponential terms. ${ }^{29}$ (The simulation also uses more conservative estimates of the criminal's discount rate, such as 25 percent or 10 percent rates.)

The time distribution of apprehension and punishment $(p(s))$ is assumed to be an exponential distribution. (This implies that most crimes are punished soon after they are committed, with the probability of punishment in any given period declining as the lag after the crime's commission increases.) The simulation employs a variety of estimates for the exact shape of the distribution, generally assuming that at least half of all crimes that are ever punished are caught and punished in less than 1 year. Finally, the probability of ever being apprehended $(\pi)$ is estimated by utilizing the Federal Bureau of Investigation's Uniform Crime Reports $1999^{30}$ data on crimes cleared by arrest, along with John Dilulio's ${ }^{31}$ estimates of the number of criminals ultimately sent to prison.

While these estimates all have at least some empirical foundation, it is impossible to estimate the true distribution of gains from crime in the pop-

\footnotetext{
${ }^{25}$ See Richard B. Freeman, Why Do So Many Young American Men Commit Crimes and What Might We Do about It? 10 J. Econ. Persp. 25 (1996); and Steven D. Levitt, The Effect of Prison Population Size on Crime Rates: Evidence from Prison Overcrowding Litigation, 111 Q. J. Econ. 319 (1996).

${ }^{26}$ See Freeman, supra note 25, at 38.

${ }^{27}$ See Cooter \& Ulen, supra note 18, at 470; and Freeman, supra note 25, at 39.

${ }^{28}$ See Wilson \& Abrahamse, supra note 17, at 363-68.

${ }^{29}$ See Swagler, Burton, \& Lewis, supra note 15, at 23-30; and Caskey, supra note 15.

${ }^{30}$ U.S. Department of Justice, Federal Bureau of Investigation, Uniform Crime Reports (1999).

${ }^{31}$ See Dilulio, supra note 14, at 12.
} 
ulation $(z(g)$ and $Z(g)){ }^{32}$ Instead, the parameters of the distribution are constrained so that the simulation produces reasonable numbers of crimes given the values of the other empirically estimated parameters. For example, in the case of burglary, Freeman estimates that there were approximately 2 million criminals of this type (or worse) in the United States in 1992. ${ }^{33}$ Thus, the values for the mean and variance of the normal distribution used in the simulation (combined with the parameters listed above), should yield results that accord with the estimate of 2 million criminals.

Many different mean and variance combinations fulfill this criterion. To narrow down the number of possible distributions even further, the distributional parameters employed in the simulation are required to produce results that are not unduly sensitive to changes in the other parameters. (In other words, there should be no "knife-edge" results in these simulations.) For example, if the true cost of imprisonment is not $\$ 30,000$ but rather $\$ 40,000$, the distributional parameters must be chosen so that the results of the simulation do not change radically. After imposing these two requirements, the "reasonable" range for the mean and the variance becomes much narrower. ${ }^{34}$

The results of the simulations are presented in Tables 1, 2, and 3. For each type of crime, several different specifications of parameter values are listed. The first column of each table presents the value of the social welfare function (equation (A1)) for different statute-of-limitation lengths when the parameters are equal to the estimates detailed above (the base case). The remaining columns in each table present social welfare when the value of one of the parameters changes from the base case specification (details are provided in the tables). For example, the second cell in column (1) of Table 1 presents the value of the social welfare function when the parameters are those detailed above (the base case) and the statute of limitations has a length of 2 years. Finally, the maximum value of the social welfare function for the given specification is presented in the final row of each column.

The values of the social welfare function (equation (A1)) are negative because there are social losses (negative social gains) associated with crime. Because of normalizations and the large number of parameter estimates, only relative values of social welfare in a given column should be compared-the

\footnotetext{
${ }^{32}$ Note that because the simulation uses the distributions $Z(g)$, the population is effectively normalized to one.

${ }^{33}$ See Freeman, supra note 25, at 28.

${ }^{34}$ The distributions employed in the simulations imply that the critical gains (gains from the crime for the criminal on the margin) when the statute of limitations is 5 years are as follows. For low-level crimes, the critical gain is approximately $\$ 250$. For mid-level crimes, the critical gain is approximately $\$ 1,000$, while for high-level crimes, the critical gain is approximately $\$ 50,000$. Note that the critical gains for these crimes are far lower than the harms they cause $(\$ 2,000, \$ 10,000$, and $\$ 1,000,000$, respectively). Crime is very inefficient from a social perspective (not surprisingly).
} 
TABLE 1

Social Welfare and LaRCENY

\begin{tabular}{|c|c|c|c|c|c|c|c|}
\hline $\begin{array}{c}\text { Statute of } \\
\text { Limitations } \\
\text { (Years) }\end{array}$ & (1) & (2) & (3) & (4) & (5) & (6) & (7) \\
\hline 1 & -60.22 & -66.12 & -68.32 & -60.77 & -56.34 & -50.63 & -58.44 \\
\hline 2 & -57.16 & -64.04 & -66.93 & -56.86 & -49.35 & -44.41 & -56.74 \\
\hline 3 & -56.51 & -63.51 & -66.62 & -55.18 & -46.50 & -42.55 & -56.54 \\
\hline 4 & -56.33 & -63.62 & -66.84 & -55.12 & -45.33 & -42.03 & -56.71 \\
\hline 5 & -56.56 & -63.95 & -67.31 & -55.14 & -44.85 & -41.91 & -56.91 \\
\hline 6 & -56.63 & -64.30 & -67.86 & -55.15 & -44.65 & -41.95 & -57.06 \\
\hline 7 & -56.68 & -64.61 & -68.40 & -55.18 & -44.59 & -41.98 & -57.15 \\
\hline 8 & -56.70 & -64.87 & -68.91 & -55.20 & -44.55 & -42.01 & -57.26 \\
\hline 9 & -56.72 & -65.06 & -69.30 & -55.22 & -44.54 & -42.03 & -57.28 \\
\hline 10 & -56.74 & -65.20 & -69.75 & -55.23 & -44.54 & -42.05 & -57.30 \\
\hline 15 & -56.74 & -65.53 & -70.70 & -55.24 & -44.55 & -42.07 & -57.33 \\
\hline 20 & -56.75 & -65.57 & -71.10 & -55.24 & -44.55 & -42.08 & -57.34 \\
\hline $\begin{array}{l}\text { Length of } \\
\text { optimal } \\
\text { statute of }\end{array}$ & 4 & 3 & 3 & 4 & 0 & 5 & 3 \\
\hline
\end{tabular}

NotE. - Methodology and sources are described in the text. Each cell presents the value of the social welfare function (equation (A1)) for a given statute of limitations and parameter specification. Column (1): Base case in which $h=\$ 2,000$, sentence $(t)$ is 6 months, the probability of ever being caught is .03 , individuals discount the future at approximately a 35 percent annual rate, society discounts the future at a 4 percent rate, and criminals experience disutility from prison of $\$ 12,000$ per year. Society faces prison and prosecution costs of approximately $\$ 30,000-\$ 40,000$ per year, and half of all prisoners that are ever punished are sent to jail within approximately 10 months. The distributional parameters are chosen so that approximately 2 percent of the population commits a crime. Column (2): Punishment occurs with a longer lag (half of all prisoners are punished within 2 years). All other parameters are the same as in the base case. Column (3): Punishment occurs with an even longer lag (half of all prisoners are punished within 3 years). All other parameters are the same as in the base case. Column (4): Potential criminals are less impatient (they discount the future at a 25 percent annual rate). All other parameters are the same as in the base case. Column (5): Potential criminals are patient (they discount the future at a 10 percent annual rate). All other parameters are the same as in the base case. Column (6): Potential criminals place higher disutility on prison (prison has a disutility of $\$ 20,000$ ). All other parameters are the same as in the base case. Column (7): The distribution of criminal gains in the population is more dispersed than in the base case (lower mean and higher variance). All other parameters are the same as in the base case.

absolute values have little meaning. A similar disclaimer applies to comparisons of the value of the social welfare function between columns (with different specifications) or between tables (with different types of crimes).

\section{B. Results of Numerical Simulation}

Table 1: Larceny $(h=\$ 2,000)$. Under almost all the specifications used in the simulation, the statute of limitations for achieving optimal deterrence for crimes with a harm of $\$ 2,000$ ranged between 3 and 5 years. (The optimal statute of limitations is given in the last row of each column.) These figures are remarkably consistent with the statutes of limitations found in many U.S. 
TABLE 2

Social Welfare and Mid-Level Crimes

\begin{tabular}{|c|c|c|c|c|c|c|c|}
\hline $\begin{array}{l}\text { Statute of } \\
\text { Limitations } \\
\text { (Years) }\end{array}$ & (1) & (2) & (3) & (4) & (5) & (6) & (7) \\
\hline 1 & -187 & -220.14 & -231.1 & -174.6 & -160.58 & -150.39 & -179.56 \\
\hline 2 & -160.6 & -205.8 & -218.8 & -139.9 & -127.26 & -129.63 & -163 \\
\hline 3 & -152.88 & -202.7 & -216.1 & -127.37 & -119.92 & -119.63 & -158.64 \\
\hline 4 & -151.9 & -197.07 & -215.3 & -122.9 & -117.4 & -116.78 & -158.05 \\
\hline 5 & -151.4 & -196.6 & -216.5 & -121.5 & -115.86 & -116.34 & -158.38 \\
\hline 6 & -151.3 & -198.3 & -218.8 & -121.3 & -115.38 & -116.33 & -158.81 \\
\hline 7 & -152.4 & -200.4 & -222.2 & -121.0 & -115.2 & -116.28 & -159.12 \\
\hline 8 & -152.7 & -202.5 & -225.6 & -121.2 & -115.14 & -116.3 & -159.32 \\
\hline 9 & -153 & -204.2 & -228.6 & -121.3 & -115.07 & -116.33 & -159.44 \\
\hline 10 & -153.1 & -205.6 & -231.2 & -121.4 & -115.08 & -116.34 & -159.5 \\
\hline 15 & -153.3 & -206.7 & -237.7 & -121.7 & -115.09 & -116.35 & -159.58 \\
\hline 20 & -153.4 & -208 & -240.9 & -121.8 & -115.09 & -116.35 & -159.59 \\
\hline \multicolumn{8}{|l|}{$\begin{array}{l}\text { Length of } \\
\text { optimal } \\
\text { statute of }\end{array}$} \\
\hline limitations & 6 & 5 & 4 & 7 & 9 & 7 & 4 \\
\hline
\end{tabular}

Note.-Methodology and sources are described in the text. Each cell presents the value of the social welfare function (equation (A1)) for a given statute of limitations and parameter specification. Column (1): Base case in which $h=\$ 10,000$, sentence $(t)$ is 4 years, the probability of ever being caught is .08 , individuals discount the future at approximately a 35 percent annual rate, society discounts the future at a 4 percent rate, and criminals experience disutility from prison of $\$ 12,000$ per year. Society faces prison and prosecution costs of approximately $\$ 30,000-\$ 40,000$ per year, and half of all prisoners that are ever punished are sent to jail within approximately 10 months. The distributional parameters are chosen so that approximately .7\% of the population commits a crime. Column (2): Punishment occurs with a longer lag (half of all prisoners are punished within 2 years). All other parameters are the same as in the base case. Column (3): Punishment occurs with an even longer lag (half of all prisoners are punished within 3 years). All other parameters are the same as in the base case. Column (4): Potential criminals are less impatient (they discount the future at a 25 percent annual rate). All other parameters are the same as in the base case. Column (5): Potential criminals are patient (they discount the future at a 10 percent annual rate). All other parameters are the same as in the base case. Column (6): Potential criminals place higher disutility on prison (prison has a disutility of $\$ 20,000$ ). All other parameters are the same as in the base case. Column (7): The distribution of criminal gains in the population is more dispersed than in the base case (lower mean and higher variance). All other parameters are the same as in the base case.

states. ${ }^{35}$ Apparently, U.S. state time bars (chosen to protect the rights of the criminal) are also relatively efficient.

These findings are robust to many different parameter specifications, such as changes in the distributional parameters or the disutility associated with

${ }^{35}$ See, for geographical examples, Ala. Code $\S 15-3-1$ (2000) (which has a statute of limitations for larceny of 3 years); Alaska Stat. $\S 12.10 .010$ (2000) (larceny time bar: 5 years); Ariz. Rev. Stat. § 13-107 (2000) (larceny time bar: 7 years); Conn. Gen. Stat. § 54-193 (2000) (larceny time bar: 5 years); Minn. Stat. $\$ 628.26$ (2000) (larceny time bar: 3 years); Idaho Code $\S 19-402$ (2000) (larceny time bar: 3 years); and Ind. Code $\S 35-41-4-2$ (2000) (larceny time bar: 5 years). The states with no statutes of limitations for felonies, however, seem to have a decidedly inefficient policy; see Ernsdorff \& Loftus, supra note 9. 
TABLE 3

Social Welfare and Heinous Crimes

\begin{tabular}{lccccccc}
\hline \hline $\begin{array}{c}\text { Statute of } \\
\text { Limitation } \\
\text { (Years) }\end{array}$ & $(1)$ & $(2)$ & $(3)$ & $(4)$ & $(5)$ & $(6)$ & $(7)$ \\
\hline 1 & -3020 & -6993 & -7893 & -559 & -2432 & -2152 & -827 \\
2 & -1634 & -2919 & -4349 & -338 & -1359 & -1121 & -453 \\
3 & -1299 & -2086 & -3388 & -259 & -1050 & -876 & -360 \\
4 & -1194 & -1842 & -2913 & -229 & -960 & -830 & -331 \\
5 & -1153 & -1760 & -2680 & -217 & -918 & -803 & -321 \\
6 & -1147 & -1722 & -2557 & -213 & -909 & -794 & -317 \\
7 & -1143 & -1719 & -2491 & -212 & -905 & -791 & -316 \\
8 & -1142 & -1718 & -2456 & -212 & -903 & -790 & -315 \\
9 & -1142 & -1718 & -2438 & -212 & -902 & -790 & -315 \\
10 & -1141 & -1717 & -2424 & -212 & -902 & -789 & -315 \\
15 & -1140 & -1717 & -2423 & -212 & -901 & -789 & -315 \\
20 & -1140 & -1717 & -2424 & -213 & -901 & -789 & -315 \\
Length of & & & & & & & \\
$\quad$ optimal & & & & & & & \\
statute of & 15 & 15 & 15 & 15 & 15 & 15 & 15 \\
limitations & 15 & & & & & & \\
\hline
\end{tabular}

NotE.-Methodology and sources are described in the text. Each cell presents the value of the social welfare function (equation (Al)) for a given statute of limitations and parameter specification. Column (1): Base case in which $h=\$ 1,000,000$, sentence $(t)$ is 30 years, the probability of ever being caught is .6, individuals discount the future at a 35 percent annual rate, society discounts the future at a 4 percent rate, and criminals experience disutility from prison of $\$ 12,000$ per year. Society faces prison and prosecution costs of approximately $\$ 30,000-\$ 40,000$ per year, and half of all prisoners that are ever punished are sent to jail within approximately 10 months. The distributional parameters are chosen so that approximately $.1 \%$ of the population commits a crime. Column (2): Punishment occurs with a longer lag (half of all prisoners are punished within 2 years). All other parameters are the same as in the base case. Column (3): Punishment occurs with an even longer lag (half of all prisoners are punished within 3 years). All other parameters are the same as in the base case. Column (4): Potential criminals are less impatient (they discount the future at a 25 percent annual rate). All other parameters are the same as in the base case. Column (5): Potential criminals place higher disutility on prison (prison has a disutility of $\$ 20,000$ ). All other parameters are the same as in the base case. Column (6): The distribution of criminal gains in the population is more dispersed than in the base case (lower mean and higher variance). All other parameters are the same as in the base case. Column (7): The distribution of criminal gains in the population is less dispersed than in the base case (higher mean and lower variance). All other parameters are the same as in the base case.

prison (see columns (6) and (7)).$^{36}$ If potential criminals are relatively patient, however, the optimal statute of limitations is much longer (see column (5)); since criminals discount the future more slowly in this case, punishments far in the future maintain some deterrent effect. As a result, punishments after a long lag are more likely to be efficient when criminals are patient than when they are impatient. ${ }^{37}$

${ }^{36}$ These findings are also robust to parameter specifications that are not presented in the table, such as changes in imprisonment costs, social discount rates, and probabilities of punishment.

${ }^{37}$ If white-collar criminals, for example, are believed to be more patient, then this result would imply that statutes of limitations should be longer for white-collar crimes. Moreover, if white-collar criminals presumably also have a higher opportunity cost for a year in jail, then this also mitigates in favor of longer statutes of limitations (see proposition $2 \mathrm{~B}$ ). 
The results suggest that the costs of choosing an overly long statute of limitations are smaller than those of choosing a statute of limitations that is too short. This is not surprising. Very short statutes of limitations will significantly reduce deterrence and lead to many more crimes. A statute of limitations of zero, for example, would imply no deterrence. The costs of such a large increase in crime will be greater than the inefficiencies of excessively long statutes of limitations. This does not imply that the costs of excessively long statutes of limitations are irrelevant, however. In column (1) of Table 1, for example, a statute of limitations of 6 years is approximately .6 percent more inefficient than the optimal statute of limitations (4 years). Since the social welfare functions represent the entire costs associated with a specific type of crime, a difference of .6 percent in social losses as a result of inefficient statutes of limitations is quite significant. ${ }^{38}$

Table 2: Mid-Level Crimes $(h=\$ 10,000)$, and Table 3: High-Level Crimes $(h=\$ 1,000,000)$. The results in these simulations share many of the features of the first simulation. For example, there is a broadly consistent range for the statute of limitations (4-8 years in the case of robbery ${ }^{39}$ and 15-20 years in the case of murder). In addition, the cost of deviating from the optimal statute of limitations is lower on the high side than on the low side. As described above, however, this does not imply that the inefficiencies resulting from overly long statutes of limitations are trivial. Finally, when criminals are more patient, the optimal statute of limitations rises.

Unlike the case of larceny, the statute of limitations tends to be longer in these simulations because the value of deterring an additional crime rises (as described in the comparative statics of the model above). Most U.S. states seem to follow this general principle by having longer statutes of limitations for more pernicious crimes. Even for the most nefarious crimes, however, there comes a point (after approximately 15-20 years) at which punishing the crime becomes inefficient from a strict deterrence perspective. This result conflicts with the statutes of all U.S. states, which recognize no statutes of limitations for crimes such as murder. This suggests that murders punished long after the fact are punished for reasons other than deterrence.

\footnotetext{
${ }^{38}$ One study suggests that the costs of all types of crime range in the neighborhood of 1 trillion dollars. This (necessarily imprecise) study, however, includes many costs not relevant to the present analysis, such as private precautions. See David Anderson, The Aggregate Burden of Crime, 42 J. Law \& Econ. 611 (1999).

${ }^{39}$ These numbers are generally consistent with the statutes of limitations for robbery in U.S. states. See, for geographical examples, Ala. Code $\S 15-3-1$ (2000) (which has a statute of limitations for robbery of 3 years); Alaska Stat. $\$ 12.10 .010$ (2000) (robbery time bar: 5 years); Ariz. Rev. Stat. \& 13-107 (2000) (robbery time bar: 7 years); Conn. Gen. Stat. $\S 54-193$ (2000) (robbery time bar: 5 years); Minn. Stat. § 628.26 (2000) (robbery time bar: 6 years); Idaho Code $\S 19-402$ (2000) (robbery time bar: 5 years); Ind. Code $\S 35-41-4-2$ (2000) (robbery time bar: 5 years).
} 


\section{Statutes of Limitations and Monetary Judgments}

The simulations presented above suggest that crimes that are punished with imprisonment should optimally have statutes of limitations that accord with those seen in practice. Since the "driving force" behind this result is the fact that imprisonment is socially costly, this analysis would not seem to apply to statutes of limitations on monetarily punishable crimes (which are not costly to impose). A modification of the model presented here, however, can be applied to statutes of limitations for monetary fines.

While the payment of a fine is not socially costly, the imposition of a fine does have costs. Trials require public expenditures. Moreover, the risk of an "unfairly" imposed fine may have social costs. ${ }^{40}$ It is also reasonable to suspect that these costs may be increasing with time (as memories fade and witnesses become harder to locate). Indeed, these costs are the same as those emphasized by conventional interpretations of statutes of limitations. Discounting, however, reduces the deterrence value of a fine imposed in the future in the same way that it reduces the value of a prison sentence. The present discounted value of a fine paid far in the future is smaller than the nominal value of the fine today. As a result, a given fine achieves less deterrence when it is imposed after a longer lag.

Thus, the benefits of a fine (increased deterrence) decrease faster than a fine's social costs as the lag between crime and punishment increases. These are exactly the conditions that led to the existence of an optimal statute of limitations in the model above. One does not need to think that the benefits of statutes of limitations are immense to justify their existence. Because statutes of limitations do not reduce deterrence so significantly because of discounting, even a small benefit (in terms of fairness or the right of repose, for example) may make time bars worthwhile.

Note that this explanation differs from the standard explanation of statutes of limitations. ${ }^{41}$ While the standard explanations emphasize the social costs described here, they tend to neglect the fact that the deterrence benefits of punishing crimes are decreasing with the lag between crime and punishment as a result of discounting. Both an increase in costs and a decrease in benefits are critical elements that mitigate in favor of statutes of limitations.

This analysis can also be applied (more tenuously) to statutes of limitations in civil actions. If the purposes of tort liability are optimal precaution and compensation for damages, then a given damage award accomplishes increasingly little as time passes. The "real value" of a given nominal tort

\footnotetext{
${ }^{40}$ The punishment of innocents may impose a psychic cost on society, for example. The probability of inappropriate sanction may well go up as the lag between crime and punishment increases. Note that these costs would also apply to crimes sanctioned by imprisonment.

${ }^{41}$ See Chavez, supra note 3; Note, supra note 1; and Posner, supra note 5, at 587.
} 
award decreases because of discounting. ${ }^{42}$ As a result, the compensatory value of the award (to the one who is harmed) is diminished. In addition, discounting erodes the value of damages in ensuring efficient precaution by potential tortfeasors. Therefore, the benefits of tort awards are decreasing with time. If one believes that the potential "costs" of tort awards (in the form of mistaken decisions and the violation of the right of repose) are not similarly decreasing with the lag between crime and punishment, then statutes of limitations for civil offenses may be efficient.

\section{Conclusion}

The discussions and simulations above suggest several conclusions regarding statutes of limitations. First, it is clear that from an efficiency perspective, every crime that society deems worth punishing by imprisonment should have a statute of limitations on prosecution. Second, the optimal statutes of limitations depend in crucial ways upon many factors, such as the harm associated with the crime and the time distribution of punishment. Finally, most U.S. states seem to have reasonably efficient statutes of limitations-only those states that do not apply statutes of limitations for even the most minor felonies have laws that are significantly different than those suggested by the simulations presented here. ${ }^{43}$

This analysis provides some insight regarding the suspension and extension of time bars. Extending a statute of limitations generally accomplishes quite little. As a result, extensions of a statute of limitations may be counterproductive. For example, the recent trend of extending statute of limitations for sexual offenses against minors until after the victims reach adulthood may be wrongheaded..$^{44}$ No one questions that the crimes are heinous. Nevertheless, the threat of additional punishments far off in the future does little to deter would-be molesters, who heavily discount the additional punishments. Moreover, the right to a fair trial in these cases has often been compromised, as memories and evidence are often quite sketchy. ${ }^{45}$ Finally, in the simulations presented here, statutes of limitations longer than 15 years are almost never cost-efficient, even for the most heinous crimes.

\footnotetext{
${ }^{42}$ Of course, if the size of the tort award is increased to take discounting and time lags into account ("prejudgment interest"), then this analysis no longer applies. Indeed, the prevalence of prejudgment interest would suggest that statutes of limitations for civil awards should be approached with greater skepticism. If the "benefits" of tort awards are not decreasing with time, then the costs of long lags between crime and punishment must be onerous to justify barring civil suits because of excessive time lags.

${ }^{43}$ See Ernsdorrf \& Loftus, supra note 9.

${ }^{44}$ See Durga M. Bharam, Statute of Limitations for Child Sexual Abuse Offenses: A Time for Reform Using the Discovery Rule, $80 \mathrm{~J}$. Crim. Law \& Criminology 842 (1989); and Josephine Bulkley \& Mark Horwitz, Adults Sexually Abused as Children: Legal Actions and Issues, 12 Behav. Sci. \& L. 65 (1994).

${ }^{45}$ See Olson, supra note 6; and Ernsdorff \& Loftus, supra note 9.
} 
The "continuing conspiracy" doctrine established by a number of court cases, by contrast, offers an example of a case where the statute of limitations should be extended ("tolled"). ${ }^{46}$ When overt (but otherwise legal) acts associated with an earlier conspiracy are committed, they cause harm in addition to the harm caused by the original conspiracy. As a result, they should be deterred. Extending the statute of limitations for the original conspiracy is one way of deterring these later harmful actions, even if the extended statute of limitations adds little to deterrence of the original crime.

These applications suggest that a proper understanding of statutes of limitations requires a careful consideration of the implications of discounting. The salience of discounting in studies of both statutes of limitations and optimal sentence lengths ${ }^{47}$ suggests that discounting may be a critical and generally overlooked topic in the analysis of law enforcement. Further exploration of the implications of discounting for optimal law enforcement is an important task of future research.

\section{APPENDIX}

\section{The Basic Model}

The model discussed here considers only crimes punishable by imprisonment within a strict-liability framework..$^{48}$ All crimes are assumed to occur at time 0 , while punishment for a crime committed at time 0 occurs with some probability in any future time period. A crime cannot be committed and punished in the same instant.

Assume a social welfare function ${ }^{49}$

$$
\begin{aligned}
U= & \int_{\bar{\delta}}^{\infty} g z(g) d g-[1-Z(\tilde{g})] \\
& \times\left[h+\pi \int_{0}^{n} e^{-\delta s} p(s) \lambda t d s+\pi \int_{0}^{n} e^{-\delta_{s \infty c s}} p(s) \alpha t d s\right],
\end{aligned}
$$

where $\tilde{g}=\pi \int_{0}^{n} e^{-\delta s} p(s) \lambda t d s$.

Each term of this maximization problem will be explained in turn. Note that all functions are continuous and differentiable by assumption.

The gain $g$ that potential criminals accrue from committing a crime is distributed through the population with strictly increasing cumulative distribution function

${ }^{46}$ See United States v. Kissel, 218 U.S. 601 (1910); Brown v. Elliot, 225 U.S. 392 (1912); and Grunewald v. United States, 353 U.S. 391 (1957).

${ }^{47}$ See Polinsky \& Shavell, supra note 11.

${ }^{48}$ The model also can be applied to crime punishable by fines, so long as there is a positive cost of imposing the fine.

${ }^{49}$ The term corresponding to law enforcement expenditures, $f(\pi)$, is suppressed here, since law enforcement expenditures are assumed to be exogenous. Thus, $f(\pi)$ will not change relative social welfare levels. 
$Z(g)$ and continuous probability density function $z(g) .{ }^{50}$ The potential losses associated with committing a crime are given by $\pi \int_{0}^{n} e^{-\delta s} p(s) \lambda t d s$, with the following:

$\pi \in[0,1]$ is the (exogenous) probability of a crime ever being detected and punished (equivalently, the probability of a crime ever being punished if there is no statute of limitations). Note that if a crime is detected before the statute of limitations has run its course, then the crime is always punished.

$p(s)$ is the (exogenous) probability that a crime committed at time 0 will be punished in time period $s$, given that the crime is detected at all. Thus, the total probability of a crime being punished in period $s$ is $\pi p(s)$. In addition, assume (for technical reasons) that $p(s)>0$ for all $s \geq 0$.

$n$ is the statute of limitations. At a time beyond $n$, a criminal cannot be punished, even if the criminal is guilty of a crime. Thus, the total probability of punishment for a crime is given by $\pi \int_{0}^{n} p(s) d s$.

$\lambda$ is the disutility a criminal receives from spending 1 year in prison; $t$ is the length of the sentence, given exogenously here. ${ }^{s i}$ Disutility from prison is thus $\lambda t$. Note that this abstracts from discounting of disutility within the prison sentence. ${ }^{52}$

$\delta$ is a potential criminal's discount rate, and $\delta \geq 0$. The present discounted value of being punished in period $s$ is thus $e^{-\delta s} \lambda t$.

Taken together, these points imply that the expected value of punishment to a criminal committing a crime at time 0 is $\pi \int_{0}^{n} e^{-\delta s} p(s) \lambda t d s$. This term is finite.

A potential criminal will choose to commit a crime only if the gains from the crime exceed the expected losses, ${ }^{53}$ that is, if

$$
g>\pi \int_{0}^{n} e^{-\delta s} p(s) \lambda t d s .
$$

If the gains associated with a particular harmful act are distributed through the population, then this implies the existence of a marginal criminal with gains associated with the crime of $\tilde{g}$ (often called the "critical gain"), where $\tilde{g}=\pi \int_{0}^{n} e^{-\delta s} p(s) \lambda t d s$. All individuals with gains from the harmful act above $\tilde{g}$ will commit the act; individuals with gains below $\tilde{g}$ will refrain.

Thus, the first term of equation (A1), $\int_{\tilde{g}}^{\infty} g z(g) d g$, represents the gains that accrue to criminals from the crimes that are committed.

The next series of terms,

$$
[1-Z(\bar{g})]\left[h+\pi \int_{0}^{n} e^{-\delta s} p(s) \lambda t d s+\pi \int_{0}^{n} e^{-\delta_{s \propto \alpha} s} p(s) \alpha t d s\right],
$$

constitutes the harm imposed on society by a crime. The term $[1-Z(\tilde{g})]$ is the proportion of the population that commits a crime. For each of these crimes, there is a harm, $h$, that is imposed on society. In addition, there are punishment costs of

${ }^{50}$ The gain $g$ might be distributed through the population because of many different factors, such as differential psychological costs of crime or differential real benefits from crime. Note that $g$ can be negative for some individuals. Note also that $g$ ranges to infinity. As a result, complete deterrence is not possible since no punishment can cause infinite disutility.

${ }^{51}$ Allowing $\lambda$ or $t$ to vary does not change the fundamental results of the model-a finite statute of limitations will still be optimal.

${ }^{52}$ See Polinsky \& Shavell, supra note 11.

${ }^{53}$ See Gary S. Becker, Crime and Punishment: An Economic Approach, 76 J. Pol. Econ. 169 (1968). 
$\pi \int_{0}^{n} e^{-\delta_{\mathrm{soc}} s} p(s) \alpha t d s$, where $\delta_{\mathrm{soc}}$ is society's discount rate and $\alpha$ is the cost of prison for 1 year. (Again, this abstracts from discounting within the prison sentence.) Finally, $\pi \int_{0}^{n} e^{-\delta s} p(s) \lambda t d s$ is the deadweight loss that results from incarcerating an inmate (from "wasted" time while the criminal is in jail).

Two assumptions are also required.

ASSUMPTION 1. $z(0) \lambda h>\lambda+\alpha$. This assumption simply implies that expanding the statute of limitations from zero to some finite amount is worthwhile. (In other words, it implies that the crime is worth punishing at all. $)^{54}$

Assumption 2. $\delta>\delta_{\text {soc }}$. This implies that criminals are less patient than society.

\section{Proofs of Propositions}

Proposition 1. All crimes that are punished should have a finite statute of limitations.

Proof. Apply Leibniz's rule repeatedly to equation (A1), obtaining the first derivative, $\partial U / \partial n$ :

$$
\begin{aligned}
= & z(\tilde{g}) \pi e^{-\delta n} p(n) \lambda t\left[h+\pi \int_{0}^{n} e^{-\delta s} p(s) \lambda t d s+\pi \int_{0}^{n} e^{-\delta_{\mathrm{soc} s}} p(s) \alpha t d s-\tilde{g}\right] \\
& -[1-Z(\tilde{g})]\left[\pi e^{-\delta n} p(n) \lambda t+\pi e^{-\delta_{\mathrm{soc}} n} p(n) \alpha t\right] \\
= & z(\tilde{g}) \pi e^{-\delta n} p(n) \lambda t\left[h+\pi \int_{0}^{n} e^{-\delta_{\mathrm{soc} s}} p(s) \alpha t d s\right] \\
& -[1-Z(\tilde{g})]\left[\pi e^{-\delta n} p(n) \lambda t+\pi e^{-\delta_{\mathrm{soc}} n} p(n) \alpha t\right] .
\end{aligned}
$$

From assumption 1, equation (A3) is positive when $n=0 . .^{55}$ As $n$ gets large, however, the terms $e^{-\delta n}$ and $e^{-\delta_{\mathrm{soc}} n}$ get arbitrarily close to zero. Since $\delta>\delta_{\mathrm{soc}}$, the term multiplied by $e^{-\delta_{\text {soc }} n}$ approaches zero at a slower rate than the terms multiplied by $e^{-\delta n}$ (recall that all terms in this expression are finite). Thus, for large values of $n$, the term $-[1-Z(\tilde{g})] \pi e^{-\delta_{\text {soc }} n} p(n) \alpha t$, which is negative (since $Z(\tilde{g}) \neq 1$ ), dominates the other terms, and $\partial U / \partial n<0$ as $n$ gets very large. Since this expression is continuous and is greater than zero at $n=0$ and less than zero for very large values of $n$, this implies that neither $n=0$ nor very large values of $n$ can be global maxima, as raising $n$ from $n=0$ raises social welfare while lowering $n$ from very large values of $n$ also raises welfare. Thus, there must be a finite statute of limitations, $n$, for which

${ }^{54}$ A less restrictive assumption would state that even if it were not optimal to have a very short statute of limitations as opposed to none at all, there is some statute of limitations that entails greater social welfare than having a statute of limitations of zero-in formal terms, that

for some $n$.

$$
\begin{gathered}
\int_{\dot{s}}^{\infty} g z(g) d g-[1-Z(\tilde{g})]\left(h+\pi \int_{0}^{n} e^{-\delta s} p(s) \lambda t d s+\pi \int_{0}^{n} e^{-\delta_{\text {socs }}} p(s) \alpha t d s\right) \\
>\int_{0}^{\infty} g z(g) d g-[1-Z(0)] h
\end{gathered}
$$

${ }^{55}$ Alternatively, one could simply assume that the total (and hence the marginal) net benefits of lengthening the statute of limitations are positive for some $n$. The proof follows with the first such $n$ replacing $n=0$. 
$\partial U / \partial n=0$ and therefore social welfare is maximized..$^{56}$ This statute of limitations is defined implicitly as the maximum of the point(s) at which $\partial U / \partial n=0 .{ }^{57}$ Another way of understanding the proof is to note that since $\delta>\delta_{\text {soc }}$, any term multiplied by $e^{-\delta s}$ converges to zero faster than any term multiplied by $e^{-\delta_{\text {soc }} s}$. Therefore, the term multiplied by $e^{-\delta_{\text {soc }} s}$ can be larger than all the other terms of the equation by any arbitrary factor. Since the term multiplied by $e^{-\delta_{s o c} s}$ enters negatively, this implies that as $n$ gets very large, $\partial U / \partial n<0$.

Proposition 2A. $\partial n / \partial h>0$.

Proof. First, note that because the statute of limitations is set at a maximum (proposition 1), $\partial^{2} U / \partial n^{2}<0$ in the neighborhood around the maximum point. Using the implicit function theorem, $\partial n / \partial h=-\left(\partial^{2} U / \partial n \partial h\right) /\left(\partial^{2} U / \partial n^{2}\right)$. From the firstorder condition $\partial^{2} U / \partial n \partial h=z(\tilde{g}) \pi e^{-\delta n} p(n) \lambda t>0$. Thus, $\partial n / \partial h>0$.

PROPOSITION 2B. $\quad \partial n / \partial \delta<0$.

Assume that

$$
\begin{aligned}
\frac{\partial^{2} U}{\partial n \partial \delta}= & -n e^{-\delta n} \lambda t\left\{\left[z(\tilde{g})\left[h+\pi \int_{0}^{n} e^{-\delta_{\mathrm{soc}} s} p(s) \alpha t d s+Z(\tilde{g})\right]-1\right\}\right. \\
& -\pi \int_{0}^{n} s e^{-\delta s} p(s) \lambda t d s\left\{z(\tilde{g}) e^{-\delta n}+z^{\prime}(\tilde{g})\left[h+\pi \int_{0}^{n} e^{-\delta_{\mathrm{soc} s}} p(s) \alpha t d s\right]\right\}<0 .
\end{aligned}
$$

Since the optimal statute of limitations occurs at a maximum, $\partial^{2} U / \partial n^{2}<0$. Thus, by the implicit function theorem and our assumption,

$$
\partial n / \partial \delta=\left(-\partial^{2} U / \partial n \partial \delta\right) /\left(\partial^{2} U / \partial n^{2}\right)<0 .
$$

Proposition 2C. $\quad \partial n / \partial \lambda>0$.

Assume that

$$
\begin{aligned}
\frac{\partial^{2} U}{\partial n \partial \lambda}= & \pi e^{-\delta n} t\left\{z(\tilde{g})\left[h+\pi \int_{0}^{n} e^{-\delta_{\mathrm{soc}} s} p(s) \alpha t d s+Z(\tilde{g})\right]-1\right\} \\
& +\pi \int_{0}^{n} e^{-\delta s} p(s) t d s\left\{z(\tilde{g})\left[\pi e^{-\delta n} p(n) \lambda t+\pi e^{-\delta_{\mathrm{soc} n}} p(n) \alpha t\right]\right. \\
& \left.+z^{\prime}(\tilde{g})\left[h+\pi \int_{0}^{n} e^{-\delta_{\mathrm{soc} s}} p(s) \alpha t d s\right]\right\}>0 .
\end{aligned}
$$

Since the optimal statute of limitations occurs at a maximum, $\partial^{2} U / \partial n^{2}<0$. Thus, by the implicit function theorem and our assumption,

$$
\partial n / \partial \lambda=\left(-\partial^{2} U / \partial n \partial \lambda\right) /\left(\partial^{2} U / \partial n^{2}\right)>0 \text {. }
$$

${ }^{56}$ There can, of course, be more than one critical point of this first-order condition. One of the critical points, however, must be a global maximum since social welfare does not attain a maximum when $n$ is either 0 or $\infty$.

57 If other variables, such as sentence length $(t)$ or enforcement effort $(\pi)$ are endogenous rather than exogenous, proposition 1 remains valid. The basics of the proof remain the same. Social welfare does not attain a maximum when the statute of limitations $(n)$ is either 0 or $\infty$ for all finite values of sentence length or enforcement effort, which thus implies that there must be an interior maximum (and thus a finite statute of limitations). 